\title{
Exploring Entrepreneurial Capabilities for International Entrepreneurship: A Study of International Entrepreneurship Sense-making Narratives in Sri Lanka
}

\author{
N. D. L. De Silva, D. M. Mudalige* \\ University of Moratuwa, Katubedda, Sri Lanka. \\ *Corresponding Author: mahilaldm@gmail.com
}

Received: July 29, 2019

Accepted: October 22, 2019

\begin{abstract}
This study aims to identify key Entrepreneur Capabilities (EC) of international entrepreneurs and recognize the significance of such ECs in the digital disruptive technology industry in Sri Lanka. Most theories and experiments are established in developed countries, and sometimes those may not be applicable in emerging countries. Reviewing and exploring narrations of successful entrepreneurs assist in recognizing their unique processes and identifying how socio-cultural and economic factors of their native country shape the international entrepreneurial process. The interviews were carried out with industry leaders who became international entrepreneurs early in their career and a qualitative case study method was used in this study. The data was triangulated using secondary documents. Universally applicable thoughts that they generated through unusual integration, cross-cultural understanding and discipline and maturity could be considered as the main themes that emerged. Relationship building capability that was supported by passion, risk acceptance and locus of control and honesty was another theme that emerged. The entrepreneurial capability was further supported by inspirational leadership, pro-activeness and opportunity utilization, language and communication ability, and flexibility. Moreover, ECs that were developed from childhood gradually supported to build the mindset of the competent international entrepreneur. The childhood experiences,
\end{abstract}


the moment of truth of their guardians and the right inspiration, developed the solid base of EC. The study revealed that it is not the size of the business which matters but the capabilities of the small firms in developing countries like Sri Lanka to sustain in international markets. The outcome of this research enhances the understanding of EC for International Entrepreneurship in developing countries. These findings can be taken to improve policies of the government and SME supportive institutions to develop new policies and procedures to develop the International Entrepreneurship culture in Sri Lanka.

Keywords: entrepreneur capabilities, international entrepreneurship, International New Venture (INV)

\section{Introduction}

The success stories which are seen today are not achieved in a day. Those had been molded based on imagination and crafted with the greatest passion. As Drucker (1987) states, those success stories have begun shaped by a courageous decision taken by an extraordinary human being on a very small scale. As per Acs, Åstebro, Audretsch, and Robinson (2016), entrepreneurship plays a vital role in the economic growth of a country by creating new ventures and by generating employment opportunities. Especially in the macroeconomy, the level of economic development depends on the level of entrepreneur engagement. Generating employments, new dynamics, innovation, productivity, and growth are the main contributions of entrepreneurs to a country (Praag and Versloot, 2007).

Sri Lankan SMEs contribute 5\% to export of the country when SMEs in the world adequately contribute 15-50\%, which means their interaction with the international market is much higher than the Sri Lankans' (Edinburgh Group, 2012). Sri Lanka has $21 \%$ of the overall global entrepreneurship index score and is ranked 94 out of 137 countries. Sri Lanka is not even represented in the Global Entrepreneurship Monitor. Looking at the Sri Lankan perspective, $65 \%$ of Sri Lankans in the 19-25-age category have 
more desire to be in public sector employment when it comes to employment due to low risks, benefits, low stress and reputation (Department of Pensions, 2015). Innovation determines the quality and dynamics of entrepreneurship ecosystems at the national and regional levels although innovative products are essential for international success, as per Global Innovation Index 2017, Sri Lanka ranked $90^{\text {th }}$ out of 130 countries.

The above empirical facts paint a gloomy picture of the Sri Lankan entrepreneurial system in general and the internationalization of SMEs. The enthusiasm stimulated for the research study about ECs for internationalization can be related to the above empirical background that is where Sri Lankan SMEs are lagging behind other similar countries in expanding and sustaining in the international arena.

However, little empirical research has been done about the success factors of international entrepreneurship in Sri Lanka (Sriyani, 2010). Entrepreneurial culture is slowly booming in Sri Lanka. The government is supporting entrepreneurs with funds; Universities are throwing exciting venture creation programs (Daily Ft, 2018). But as per the pilot research conducted by the author, young entrepreneurs in Sri Lanka are following and emulating foreign entrepreneurs such as Steve Jobs, Richard Branson, Jeff Bezos, Elon Musk, Reid Hoffman, etc. They tend to adopt those foreign strategies and processes. Commencing a venture in Sri Lanka is unlike a startup in Silicon Valley, as the economic factors, socio-cultural factors are too different and broad (Hofstede et al., 2004).

Coviello (2015) says the theories and experiments are established for developed countries, and sometimes those might not be able to apply to develop or emerging countries. Sirisena (2015) states an entrepreneurial mindset, hunt for opportunities and kick off on a new venture are affected by socio-cultural and economic factors of his/her native country. Dilmah entrepreneur; who took the name of Ceylon tea to the international with mind-blowing fusions of novel tastes of Ceylon Tea, Tony Weerasinghe; 
Millennium IT entrepreneur and Peter De Almeida; entrepreneur who made a huge difference in the Sri Lankan digital disruption which could make an impact on the international market, Mahesh Amalean; MAS entrepreneur, who created world-class family business in the garment industry are the characters to be identified and followed to learn and craft another Sri Lankan entrepreneurial story.

Zhang, Tansuhaj, and McCullough (2009) state that there is a lack of studies on firm-level capability and individual capability, and a lot of studies should be done on those. Because of that, the knowledge of how the small firms perform and the major issues and challenges they have to face when establishing their organization in the international market place is still a question to find out. Also, Cavusgil and Knight (2015) state that even though many thought-provoking works have been done around the world in the stream of SMEs, still the knowledge on SME internationalization is inadequate to make decisions on developing strategies. Another important fact is, a major proportion of those empirical studies have been done making developed countries as the base. Thus, Karra, Phillips, and Tracey (2008) say even though several types of research have been done for entrepreneurial capability required for conventional entrepreneurship, little has been done about entrepreneurial capabilities needed for international entrepreneurship. Moreover, in this stream of research, most of the explorers have used quantitative research methods. But these are limited in terms of in-depth understanding of the entrepreneur and the individual human factors of capability building.

The main research questions of the research are "How entrepreneurial capabilities are built and developed within Sri Lankan Entrepreneurs and What entrepreneurial capabilities did Sri Lankan entrepreneurs demonstrate when they initiate and engage in International entrepreneurship?"

The rest of the paper is organized as follows. The literature review is in section 02, which describes perspectives, models, and theories about 
international entrepreneurial capability. A literature review helps to understand and identify the IE and EC to be successful in general. Section 03 explains the methodology of the research, data gathering, analysis, and the framework used. Section 04 shows the outcome of the data gathered and Section 05 includes the discussion of the main findings, conclusion and implications.

\section{Literature Review}

An entrepreneur's process of managing businesses across the national border is international entrepreneurship (Treasure, 2010). Even though much research has been done regarding the positive side of the EC, it is important to understand the factors that can affect EC as well. Two aspects can be identified in this regard. As per Driessen and Zwatt (2010), one aspect is based on an objective evaluation approach for entrepreneurs and the subjectivist theory of entrepreneurship focusing on individuals concerning their knowledge, resources, skills and the process of discovery and creativity. Based on entrepreneurial competence theory, Driessen and Zwart (2010) identify motivation, characteristics, capabilities, and knowledge as the four components that determine entrepreneurial competence. As per capabilities, once it is identified, entrepreneurs can learn and change and develop the capabilities.

Entrepreneurs are always action-oriented people; entrepreneurial capability harmonizes with the personal capability of the person. With that, because these capabilities come from the deep down roots of the person, personal capabilities are considered as one of the ECs (Obrecht, 2004). As Obrecht (2004) says, personal temperament or orientation goes beyond trait approach or cognitive approach as it is always associated with 'action' as an aspect to measure and it is an expression of someone's capability. Following McClelland's motivation and emotion of an entrepreneur theory, Roberts (1991) had tested technical entrepreneurs' need level and the company performance. He concludes $80 \%$ of high growth companies were driven by entrepreneurs with high motivation and need for achievement. Personality 
attribute is another important factor in creating personal entrepreneurial capability. Not only that, it is believed that personality traits have significance in making successful entrepreneurs. Taking a risk and starting a business, surviving in an uncertain environment and making profits depend on strong personalities, says Åstebro, Herz, Nanda, and Weber (2014) highlighting from Frank Knight's publication risk, uncertainty, and profit.

Societal entrepreneurial capabilities are genetic points, which are embedded in the entrepreneur, which help to make him unique from others (Obrecht, 2004). That highlights the mutual connection with the entrepreneur and his community (Nijsen, 2002). Further, Obrecht (2004) describes a community or the society in which an individual life has a greater impact on destiny; in that scenario, being responsible for the values that the community shares are one of the greater challenges an entrepreneur faces.

Entrepreneurial Orientation (EO) of the entrepreneur and ECs are used to measure similar aspects of the entrepreneur. It was found that both EO and EC had a positive relationship with internationalization according to the research of many scholars (e.g., Deligianni et al. 2015). In research carried out in Sri Lanka by Mudalige, Ismail and Malek (2019) established that EO and social capital have a positive influence on SME internationalization.

Triad model of entrepreneurial capabilities provides the framework for the development and origin of entrepreneurial capabilities. It mentions what the main components of personal, organizational and societal capabilities that are important to develop balanced entrepreneurial capability are. Triad model illustrates the personal capabilities that are rooted in the entrepreneur's personality, the knowledge as a powerful tool, organizational capability with strategic directions and HR practices and societal capabilities that depict the ethics, networking ability, entrepreneurial governance and the finesse (Obrecht, 2004).

Talent, temperament, and technique is called entrepreneurial highperformance triangle (Figure 1) developed by Bolton and Thompson (2004), 
by connecting capabilities of proactive personality, entrepreneurial alertness, opportunity spotting, entrepreneurial governess, finesses, practices in team formation, managing organization, networking abilities, respecting and responding to social ethics together. Here a few aspects remain unclarified. When many people are trying to become entrepreneurs, only very few achieve it. Also, most entrepreneurs are stuck at the local market, but some become globally.

Figure 1: The performance triangle

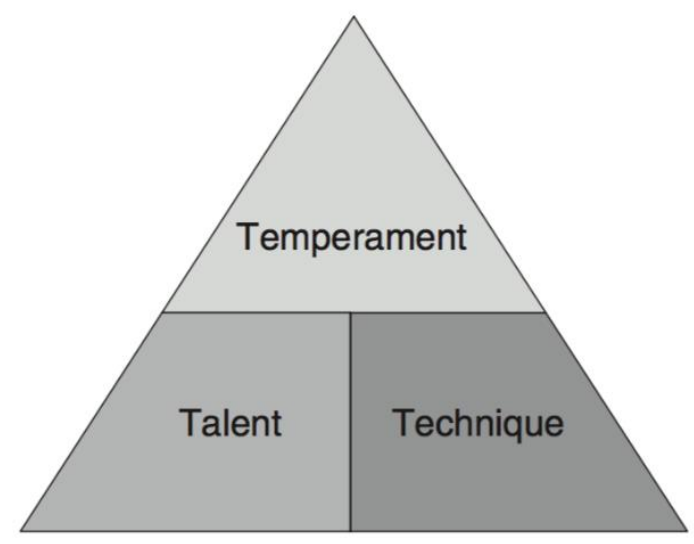

Source: Bolton and Thompson, 2004

\section{Methodology}

A qualitative study can be taken as a thorough, philosophical description of a case that can be used to understand the social phenomenon and the inner state of human behavior (Stake, 1994; Yin, 2003). This research uses the case study method. This research takes sense-making personalities/case studies who had proven themselves both local and IB pitch being Sri Lankan descent entrepreneurs to generate esteemed rich data (Hewapathirana, 2009; Karra, Phillips, \& Tracey, 2008)

The concept of sense-making is the human driving factor. Wenger (1998) illustrates all the experiences we confront in our day-to-day life are endless compromising processes. These compromises we do with our inner world, surrounding directly or indirectly. These highlight the importance of one's Peradeniya Management Review - Vol. I, Issue.02, (December) 2019 
life experience as these continuous processes or interactions make a sensemaking life. Dervin (1998) introduces the concept of sense-making with three main assumptions. Those human beings are unique individuals and the uniqueness creates different actions relates to various circumstances are the first two assumptions. The imperfection of the world is considered the third assumption. In this scenario, each human being takes actions diversely, which makes each result differently. This concept further emphasizes the uniqueness of each entrepreneur as well. Purposeful sampling (Extreme deviant case sampling) is selected due to its information richness and being unusual which means the participants are outstandingly successful or noted failures.

The research adopted specific criteria for the participant selection process. Participants should be international entrepreneurs of Sri Lankan descent (origin) and should be the founder or co-founder of the organization. Participants should have ongoing international businesses in service, joint ventures, or partnerships. For past 12 years or less than 12 years, they should have maintained growth in their international business (There are number of arguments with the age of the International New Ventures (INV) but the age of INV goes up to 12 years since the inception McDougall, Scott, \& Oviatt, 1994; Zahra, Neubaum, \& Huse, 2008). Moreover, document analysis helped to validate or triangulate the findings. Documents were useful to validate due to the richness of the data because that information was inclusive as much as possible and was up to date. Web articles, blogs, Magazine articles, newspaper articles, talk shows, open forums were used to get information (Patton, 2002; Densecombe, 2003).

In-depth interviews strive to get the participants to talk about stories, incidents, experiences, feelings, opinions, judgments, and knowledge of the participants. Therefore, pre-prepared sets of questions have not been used in this research except for a few guidelines, which will help the answers to be more focused. Also, as mentioned earlier narrative researches help people to unfold their world, their patterns, behavior, etc. Because of that, the approaching style matters a lot. Respondents spoke about their 
childhood, parent, and family history, how they started the business, struggles they had, how they find solutions, perceptions about industry, life, etc. Other than the main questions planned, probing questions such as, "What was your turning point, how did you begin, and when did you begin?", "How was the response you got from the family/friends/relations when you were going to start-up?", "How did you manage that response?", "Who were your original partners and are they still with you?", "How did you find your first client?", "What problems did you face while internationalizing?", "How did you solve them?", "Why did you solve them that way?", "Tell me your story of doing international business", "Do you believe you have been successful in international business? Why so?" and "Were used to keep them on track."

The challenge for the author was to identify common patterns and unique facts and themes related to entrepreneurial capabilities, most importantly, as participants initiate and continue their IE. In data coding, firstly, the data with similar meanings were classified and given the same code. Then the codes having similar meanings were grouped to make categories. Codes with similar meanings were identified through words, activities, feelings, topics, etc.

\section{Results and Discussion}

\subsection{Information about Respondents}

All three of the research participants are co-founders of their companies, which started in Sri Lanka and operated globally. All three companies are INVs and they are into digital disruption-software business and their services/products are sold internationally.

Pattern recognition was used to make sense of field research. By spotting like phenomena in interviews or ideas, similarities, or commonalities were recognized. Patterns helped to understand larger truths about behavior that go beyond the individual. Patterns helped us discern "rules" for how systems or people behave. These identified patterns help to predict how 
future entrepreneurs in the internationalization process respond to environmental triggers.

Table 1: Description of Research Participants (Developed by author)

\begin{tabular}{|l|l|l|l|l|l|}
\hline Participant & Gender & $\begin{array}{l}\text { Number } \\
\text { of years } \\
\text { in IE }\end{array}$ & $\begin{array}{l}\text { The industry of the } \\
\text { participant in }\end{array}$ & Position & $\begin{array}{l}\text { International } \\
\text { locations }\end{array}$ \\
\hline Mr. DG & Male & 10 & $\begin{array}{l}\text { Disruptive technology/ digital } \\
\text { transformation /software } \\
\text { business }\end{array}$ & $\begin{array}{l}\text { Co- } \\
\text { founder }\end{array}$ & $\begin{array}{l}\text { USA, UK, } \\
\text { Africa, } \\
\text { Australia }\end{array}$ \\
\hline Mr. HP & Male & 25 & $\begin{array}{l}\text { Disruptive technology/ digital } \\
\text { transformation /software } \\
\text { business / }\end{array}$ & $\begin{array}{l}\text { Co- } \\
\text { Founder }\end{array}$ & $\begin{array}{l}\text { Asia, Middle } \\
\text { east, }\end{array}$ \\
\hline Mr. PA & Male & 10 & $\begin{array}{l}\text { Disruptive technology/ digital } \\
\text { transformation /software } \\
\text { business / Business } \\
\text { development }\end{array}$ & $\begin{array}{l}\text { Founder } \\
\text { CEO }\end{array}$ & $\begin{array}{l}\text { Plugging } \\
\text { with a global } \\
\text { company }\end{array}$ \\
\hline
\end{tabular}

Case Participant 1: Mr. DG

Mr. DG is coming from a middle-income family in the sub-urban in Colombo district. His father was an Italian-speaking guide/ lecturer, and his mother was a housewife. He studied in a reputed Buddhist school in Colombo. After his secondary education, he has done his tertiary B.A.Sc. (Bachelor of Applied Science) in Australia. There he learned about information sciences and support services. That is where he first learned about information technology and software (IT). By that time during 1995-1999, he was engaging in tutoring what he learned and practicing in software fundamentals, programming and database subjects which gave him a good knowledge in the stream.

At the age of 35, in 2012, Mr. DG started his company because of the passion for technology and thirst he had for innovation. They went back to basics. Then Mr. DG, with the other 2 partners, had looked at what was 
missing when Company $\mathrm{V}$ was growing. Next, they looked at what exactly they wanted to do. Further, they thought about what they could do to make a real disruption with the technology they had.

\begin{abstract}
"Disrupt in a positive way and to transformation to either to an individual either a company to get the benefits that they want or the KPI for them to achieve their goals. So, then we thought we are going to start focusing on building products".
\end{abstract}

Case Participant 2: Mr. HP

The story of Mr. HP is exceptional and most probably the only Sri Lankan story of a high school startup that could reach up to a multinational scale. Mr. HP is coming from a middle-income family, where his father is from down south. Mother was a schoolteacher, and father was a government servant. His future got transformed in 1989 after seeing commodore 64 at his neighbor's house. His father bought him Laser 350 computer that he could hook into television, but again that could do only programming.

The confidence he gained through self-learning and believing in himself made him a person with a high technical background, which he believes it brought a positive impact on the companies he formed.

"I was just passionate about it........I'm coming from a very good technical background, which is a very important thing actually; So anyone can't come and mess with me".

Case Participant 3: Mr. PA

Mr. PA is coming from a Catholic, lower-income family with eleven children. His father died at the age of 64, leaving all the responsibilities on the mother and the elder kids. As a little child, he had to do everything by himself. 
"There was no one to pamper us. We had to do everything by ourselves. Freedom and independence made us responsible. At the same time, imagination and creativity were infused with us. I think that's the secret".

His foundation was enriched with literature, drama, social work and the love for Marxism, which he believes, gave him a sophisticated background as a low-income child to rise above the sky. Mr. PA is special, because of two reasons; founding Sri Lanka's biggest software innovation company and also he is in the process of internationalizing his second venture. The second company that he founded is also in the software business; currently, the company serves telecom operators, banks, government institutions, and larger enterprises to get the best out of cutting edge technology such as big data, data analytics, and predictive data. Ten years before he started the company with 13 people and now it has increased to $200+$ number of people with 20 million USD in revenue. His unique characteristic of "visionary leadership" made him a role model in his industry.

"We can identify, understand, and adopt technology early, and use it to build a value proposition. We can visualize how technology can be used to create value for business".

This research strived in quest of how international ECs are developed in Sri Lankan entrepreneurs. When reading the narrative transcripts several times to get an understanding of how these entrepreneurial capabilities got inbuilt and developed within Sri Lankan international entrepreneurs, three main themes emerged. ECs that were developed from childhood gradually supported to build the mindset of the competent international entrepreneur. The childhood experiences, the moment of truth of their guardians and the right inspiration, developed a solid base of EC. 


\subsection{International EC development - Theme\#1 "Childhood is the foundation."}

The main essence related to the phenomenon "development of entrepreneurial capability" was identified, as "Childhood is the foundation." There has been an established pattern of the lived experience of a worthy childhood for all the participants which they memorize happily.

Literature showed childhood experiences as one of the major areas that develop capabilities and entrepreneurial intentions of a person. Childhood is recognized as the foundation to build a successful entrepreneur (Drennan, Kennedy, \& Renfrow, 2005). It is understood that the childhood of a person is the best foundation for him to become an entrepreneur. The social, emotional, and creative development that is important to affect the child's future can be experienced only during childhood. So, Childhood plays a vital role in an entrepreneur's life-shaping their capabilities, senses, knowledge and cognitive skills to face challenges. Those factors were apparent through interviews of each participant. It was found each one of them learned creativity, consciousness, confidence and entrepreneurship intention from childhood.

Mr. PA emphasizes, he had learned about problems and problem-solving skills. He believes that his creative side was brought out through that.

"I grew up with a lot of freedom...we played, I did drama...literature...Marxism...so I would address problems and solve problems. So, I think that's the creative side of me.... That's the secret".

This was further proven by Mr. PA's own words at TEDxColombo (2017),

"I was wondering what would be the ideal worth sharing. And I thought if I connect the dots so to speak in my life and think of the most important moments, I quickly realized there's very little to do with technology and business that I'm involved in today.... Pathetic. Education.. think what we have put on our children? They took these children and put them into 
nationally competitive examinations to get the race to the top to get a better-funded school for secondary education. And in the process, we are killing the human spirit. We should sharpen the creativity of children and use that for better purposes of world, as childhood is the best time to lay a good foundation to create a revolution".

This was further evident by Mr. HP's own words.

"1988 and 1989 was a very bad time in Sri Lanka due to riots. Schools were closed, power cuts. Etc. But that was the time I had the freedom and learned everything by exploring by myself. I was not confined to traditional education, but I was inquisitive about solving practical problems. Because of that, I have a very strong technical background. I self-studied. I mastered 6 computer languages within 6 months. I was a programmer since age 14".

They all expressed positive views about how their childhood habits and activities have helped them in their current international entrepreneurship journey.

\subsection{International EC development - Theme\#2 "Right inspiration.”}

In literature, the importance of inspiration for a person for his / her development to build a lifelong lesson is highlighted (Bialik, Bogan, Fadel, \& Horvathova, 2015). In that scenario, having the right inspiration at the right time made them entrepreneurs who could expand their businesses internationally. Their own words from interview transcripts and speeches from open forums give evidence and prove the point.

Mr. PA's words are the best evidence for that.

"When I was 15, I was introduced to Marxism by my friend Francis. He took me to see this veteran trade unionist call Bala Tampoe. And Bala Tampoe was an extraordinary man, and it was a life-changing moment for me. Because Bala was a great socialist in the true sense of the word. And he was a humanist and a brilliant lawyer probably one of the best this country has produced. Yet he chose not to accumulate wealth for himself but 
dedicated his entire life for the upliftment of the working people of this country. With my relationship with Bala I became socially conscious".

Also, Mr. HP mentioned

"I started reading about Microsoft, and that was when I was in grade 10.....We wanted to create something like Microsoft. You know... we copied them, the way they did things everything we imitated them. So even though we were kids, we learned to do everything very professionally because we were following Bill Gates and Microsoft. Why I was so excited about Microsoft is because it was also a high school startup. So I was thinking why can't we do that".

\subsection{International EC development - Theme\#3 "Moment of the truth of guardians."}

Childhood is the foundation for a better man in the future (King, 2015). Childhood has to be nurtured with the greatest care, and indispensable support has to be given by the guardians at the exact moment to get the best out. This is something that all three participants have expressed with so much gratitude. That exact crucial moment is the moment of truth. Moment of truth with the meaning of the right moment, which a particular decision has to be made, had helped these participants to come in their entrepreneurial journey till today. Because they feel gratitude for what they have received by the guardians, today they help other needy children to become industry leaders.

\footnotetext{
"After getting to know that I know programming, the master -in-charge (headmaster) came and spoke to me and when I told I know this stuff he asked "can you do a class for other students to learn... teach them computer". So I started classes in School. Even though I was new to the school, I became the president of the computer club".
}

The decision made by the school/school headmaster without any hesitation that day had made a huge impact on society today. Because of that, he used to say how his school changed his life. Moreover, he mentioned the Peradeniya Management Review - Vol. I, Issue.02, (December) 2019 
difference he understands in the school system then and now relating to the opportunity he was given by the school when he was a child, that had taught him leadership and how to be a responsible innovator.

Mr. PA brought a very controversial point,

\begin{abstract}
"I'm coming from a strong Catholic family. My father was a very conservative Catholic and he had very strong opinions about the status quo and not to challenge seniors, teachers, etc. He tightly controlled my views and thoughts. No freedom. Because he died my life had changed. Otherwise, I would have not been talking to you. I would have become an ordinary fellow, maybe as he would have controlled my mind to be very religious. Also, I learned Marxism from my mother who was a widow at the age of 23 with 11 children and facing an utterly terrible moment. After the death of my father, I learned to destroy fear and shame and explore new ideas, to go forward and take action. My mother was the inspiration".
\end{abstract}

As a group of people emerging from a family-centered cultural background, it's a controversial thought that came up. But it shows what impact a parent could have on a child. Various types of experiences the child has have had a great impact on intention building for entrepreneurship. Difficult childhood is the factor that had helped and motivated him to become what he is today.

This research also aimed to investigate what entrepreneurial capabilities did Sri Lankan Entrepreneurs demonstrated when they initiate international entrepreneurship. The findings converge to a few main themes.

\title{
4.5 EC demonstrated - Theme \#1: “Local Idea-Universal Execution.”
}

The main spirit that relates to the concept EC of these research participants was identified as the capability of the "Local Idea-Universal Execution" thought process. These thoughts further can be explained as "Universal Applicable Thoughts." The specialty of the ideas that these research participants have come up with is that they can be applied in any part of the world. Also, this can be described as "human Insights." In 
internationalization, the ability to understand the requirements of people beyond the cultural and social contexts is critical.

\begin{abstract}
"Elderly population is increasing. Taking care of elder parents is becoming a difficulty for the new generation due to their busy work schedules but also, they are concerned about what will happen when the parents start living alone. So children are concerned about the age-care homes they chose for parents. So, what can we do to make their lives so easy and hassle-free? How to give them peace of mind?" (Mr. DG).
\end{abstract}

Relating to this case, the finding is that the elderly population is increasing. Simultaneously, the lives of their children are also getting complicated. They want to take care of their parents, but they don't have time. It's a wearable technology, which can generate messages about the elderly parent, is the universally executable thought to serve the increasing elderly population worldwide.

\begin{abstract}
"We have to make something that the other human beings also will be able to continue that cycle, that's how you need to think, sustainability in a more empathetic way. When you think about an idea, it has to be globally applicable and also it should have a cycle for another one to consume and develop further" (Mr. HP).
\end{abstract}

Universally applicable ideas are supported by three sub-themes.

\title{
4.5.1 Atypical Integration
}

Being able to listen beyond what others said while connecting the dots was emerged as an important essence because it shows how capable they are learning from day-to-day life, from society, and catching ideas to develop products with actual needs. This can be called "Atypical Integration." Mr. PA stated that he learned through people, by looking at people, listening to what they say. He further emphasizes how that had helped him to shape up his life later. Now he is in the process of atypical integration to generate good business ideas. As a result, they tend to innovate new products that 
can be sold internationally. The essence was apparent from Mr. PA's own words.

\begin{abstract}
"We meet many people in our lives. When we meet them, we have to think about how can we learn something from them. That's a different capability I guess. I cannot teach you how to do that. For example, you and I sit while somebody will be speaking. I will get something out of it very differently than the way you get it. I'm not saying I will be better, that's not it. But getting something out of that. Because you can take down exactly what he said. But the importance is you should be able to trigger something in your head out of what he said, what he didn't say. Ah! Interesting that is what Steve Jobs said connecting the dots. We should be able to link one from another to another".
\end{abstract}

\title{
4.5.2 Cross-cultural understanding
}

Culture and how it affects people is already proven. Culture shapes people, beliefs, living patterns, likes, dislikes, and behavior. Having a good understanding of different cultures is important to do good business with them. Knowledge about cultures can be referred to as cross-cultural understanding. Also, most importantly, cross-cultural understanding is important to execute an idea in any part of the world without any hassle. All three participants have demonstrated the need for cross-cultural understanding.

\subsubsection{Discipline and maturity}

All the participants have shared broad thought processes for product or service innovation in digital disruption. There they took the world as one unit, or they took people as one unit when addressing the issues or identifying gaps in markets. But, having a bigger picture is not enough for a universal execution but having steps that go hand in hand until the final step is important. That they introduce as "discipline." Discipline is another important capability that could be identified among all three in common. 
"Number 01 is, you need to have a good product idea. But having a good product idea is not enough. There are other things you need to pay attention to very closely. Sometimes the idea is good but it might have already been introduced and done and established outside. You have to research. Then we need to look at the business canvas, so the first is having the idea. Then, the idea, we need to figure out how it can be made an ecosystem with that we need to go and see who are the competitors and what has been done outside, what is the value proposition that it can bring. Then the market segment you are planning to cater. Finalize the features. Then do an MVP. The total MVP concept is really important as it helps you to evolve. Make assumptions but also do a proper due diligence. Have a plan A and plan B. Focus. Then understand not every product be successful overnight. Some take time. Phase-out your plan. Draw the road map. If you want to be in the business, the product road map is important as well as patience" (Mr. DG).

Mr. PA and Mr. HP also had similar thoughts regarding the significance of discipline, which had helped them to be on track. Further, this research delved into other main factors that define international entrepreneurs in the local context.

Organizational capabilities can be found as an entrepreneurial capability that supports international entrepreneurship. The theories say a small business needs good HR practices, policies, and people handling skills of the owner and team spirit to build a capable organization. But Sri Lanka as an Asian country, the concept that drives a company to success is called "Family" which aids in keeping and construct long-lasting relationships. Correspondingly, among many friends, there is a type of friend called "noble friends."

It is evident by research participants from their own words.

"This is my family, MI Company... but W company is my extended family. We brought out those two together, working hard. I made strategies to sell the products we made at W Company to sell in the Middle East, Asia. I spoke at their conferences. When I left W Company it was emotional for all 
of us. But I had to leave my extended family for my Family "MI Company" (Mr. HP).

It is further explained by Mr. DG how he named his company and the values he tried to maintain in the company. All these are interconnected with family and noble friend concepts.

"Mitra in Sanskrit stands for friendship-Mitra. We look to embrace values and we want to recidivate that across the entire company. Even if a guy would have joined yesterday, I want to make sure that he also runs with those values. The values mean, in a team if you are a friend-Mitra we never want to let a friend down, we look after just like a family member. That's the concept behind our company name"(Mr. DG).

Doing what you love or passionate about emerged as the prime concern of the business. This came out as an important essence because they were not after money or profit. It was a universal understanding that these participants took business and profit as a byproduct for them.

This was proven by Mr. HP's own words.

"We started this when we were at school. It was not a company. It was a fun thing we did. I feel I'm still at school, even though I'm old now (with a laugh). Because this is what exactly we are doing today even after 25 years, doing what we love".

This is further proved by Mr. DG's own words, which express how they call their business as what they love to do."I always loved to find ways to help people. And that is exactly what I'm doing right now using technology".

Risk acceptance and Locus of control are other important aspects. Without pain, no gain was another important essence that has emerged. They all have taken risks in international venturing together as a family, as a good set of friends. This is proven by their words. Especially by Mr. PA and Mr. DG, as by the time they thought of their venture, Mr. PA was running a 
successful international business and Mr. DG was in a high position in Company $\mathrm{X}$.

\begin{abstract}
"We started N company in 2008, what we wanted was to help businesses to be radical and transformed using technology. IT should not be kept in the company's department doing ordinary day-to-day internal work. Technology should make positive business results. Thirteen of us left our steady jobs because we believed that this could be done. Because we believed we could do this. And ten years later, today we can say we have achieved it" (Mr. PA).
\end{abstract}

Mr. DG further emphasizes:

\begin{abstract}
"We didn't have capital. All of us were bootstrapped. I mean when we started for one, all three of us didn't even think of a salary. We always thought to reuse the money we had allocated as our salary. We all did a little outside job to find some money. But the good news is we were cash positive since day one. I don't know about others. I'm in to take a lot of risks".
\end{abstract}

The risk acceptance level and the confidence to take risks also show the level of locus of control they have in them and their team.

Finally, inspirational leadership and honesty were identified as defining characters of all three entrepreneurs. They have demonstrated high emotional intelligence and tolerance. Other than that all of them have used the personal life philosophy for their business growth. Each participant had his or her theory of living life. That philosophy has reflected in the current business they are in, current products they innovate. Mr. PA had stated during the interview that due to the inspirations he gained in his life since childhood, he became a "socially conscious person." Also, he stated the purpose behind his business is not using technology and innovating products but enhancing humanity and helping society and sustainability. Similarly, Mr. HP also has stated, doing something to solve social problems, cultural problem and helping people are the purpose of his business. 
Having different interests is the foundation of new idea generation. In this scenario, being a polymath was the path to the success of these participants. As per Ernest Boyer, the future belongs to the integrators. People have at least three diverse interested fields and they integrate those to generate the top 1\% skillset (Root-Bernstein, 2009). They bring the best of humanity and become more efficient in their main field when others are becoming specialized in their field by focusing on the general knowledge they have in their field. Being a "T-Shaped" (Figure 2) person has become more popular around the world to become successful. Modern polymaths learn knowledge across the fields and then integrate them into one to innovate new avenues and become a disrupter (Gladwell, 2009).

\section{Figure 2: T Shape Personality}

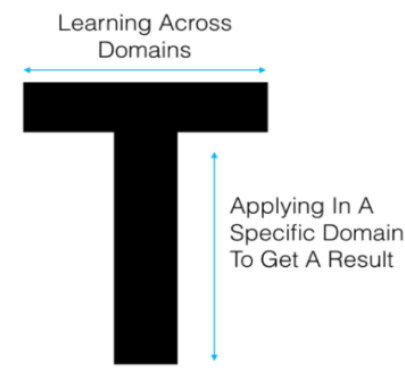

Source: Simon, 2018

Figure 3: Glocal Entrepreneurship Capability Model for International Entrepreneurship

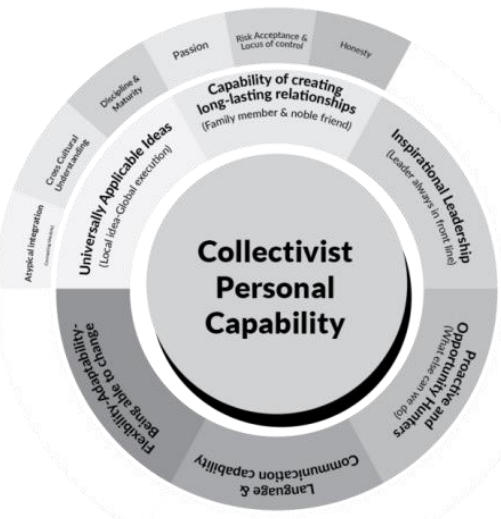

Source: Constructed by author

Peradeniya Management Review - Vol. I, Issue.02, (December) 2019 
Based on the research findings, the "Glocal Entrepreneur Capability model" (Figure 3) can be developed as an EC model for international entrepreneurship for Sri Lankans.

This model is named "Glocal" - to symbolize a local reaching the global market. Humans contrast with capacity. Each international entrepreneur doesn't have an identical degree of each capability, as each entrepreneur is different. Therefore, by looking at the level of capabilities of each entrepreneur, international entrepreneurship identities can be created. Identifying the degree of capabilities of each person is a supportive factor to groom him/her to achieve the prospect. These findings will be essential in the establishment and management of successful international businesses in digital disruption.

\section{Conclusion}

When addressing how ECs were built and developed within International Entrepreneurs born in Sri Lanka, the present-day study found major essence with two sub-themes. The main essence that emerged out of the research was "childhood." Inside the main theme of childhood, the right inspiration and the moment of truth of their guardians; helped all the participants to create a solid foundation for entrepreneurial capabilities for them to do innovation and reach the international market. The entrepreneurial spirit is something that has to be included in early childhood education.

Also, this study shows that it is not only the education system that has to be amended but also the support from the family and society. Parents, together with all the guardians such as teachers, coaches have to be responsible for what their children become in the future. They always have to give them the right inspiration. Show them the world and the moment of truth; they should take corrective actions. Inspiration is crucial for someone's life as inspirations create lifelong lessons to motivate and awake synergy. 
The overreaching themes identified about how entrepreneurial capabilities are built Universal applicable thoughts (local idea-universal execution), capability of building long-lasting relationships (treating business as a family member and noble friend), Inspirational Leadership (Leader always in the front line), proactive and opportunity hunters (What else can we do?), Language and Communication capability and Flexibility (Being able to change). The facts identified through these themes were the entrepreneur capabilities demonstrated by Sri Lankan entrepreneurs when initiating and engaging in their INV.

Policymakers could get valuable insights to craft entrepreneurship education and develop entrepreneurship spirit within Sri Lankans who are scared of accepting risks. This research will help to upgrade the Sri Lankan education system to inject the entrepreneurship spirit to let the children be impressed and have much broader visions. In the long run, the findings will support Sri Lankan entrepreneurs to be more successful and competitive in the international market. Also, this will inspire small business owners, entrepreneurs, and people who are yet to find out the global entrepreneurs within themselves to arise and build the International ECs.

\section{References}

Acs, Z. J., Åstebro, T., Audretsch, D. B., and Robinson, D. T. (2016).Public policy to promote entrepreneurship: a call to arms, Small Business Economics.

Allen, I. (2016).International Entrepreneurship Theory: Past, Present and Way Forward. Entrepreneurial Business and economic review, Vol. 4 No 4.

Åstebro, T., Herz, H., Nanda, R., and Weber, A. R., (2014).Seeking the Roots of Entrepreneurship: Insights from Behavioral Economics.Journal of Economic Perspectives, Vol. 28 No 3.

Bolton, B., and Thompson, J. (2004).Entrepreneurs :Talent, Temperament, Technique ,Elsevier Butterworth-Heinemann.

Bialik, M., Bogan, M., Fadel, C.,\& Horvathova, M., (2015).Character Education for the $21^{\text {st }}$ Century: What should students learn?.Center for Curriculum Redesign 
Cavusgil, S. T., and Knight, G. (2015), "The born global firm: An entrepreneurial and capabilities perspective on early and rapid internationalization.Journal of International Business Studies, Vol.46 No 1.

Coviello, N. (2015).Re-Thinking research on Born Globals.Journal of International business studies, pp.17-26.

Daily Ft (2018).Enterprise Sri Lanka to create 100,000 entrepreneurs.http://www.ft.lk/front-page/Enterprise-Sri-Lanka-tocreate-100-000-entrepreneurs--Mangala/44-656867

Deligianni I, Dimitratos P, Petrou A, Aharoni Y (2015).Entrepreneurial orientation and international performance: the moderating effect of decision-making rationality.J Small Bus Manag 54(2):462-480. https://doi.org/10.1111/jsbm.12152

Densecombe, M. (2003).The good research guide for small-scale social research (2 ed.), McGraw HIll: Open University Press.

Department of Pensions, Sri Lanka. (2015).Future Employment desires of age 19-25 in Sri Lanka.

Dervin, B. (1998).Sense-making theory and practice: an overview of user interests in knowledge seeking and use.Journal of Knowledge Management, 2: 3646.

Drennan, J., Kennedy, J., \& Renfrow, P., (2005).Impact of Childhood Experiences on the Development of Entrepreneurial Intentions. International Journal of Entrepreneurship and Innovation.

Driessen, M. P., Zwart, P. S., (2010).The role of entrepreneur in small business success: The Entrepreneurship Scan. The Netherlands, University of Groningen.

Drucker, P. (1985, May-June).The discipline of innovation. Harvard business review, pp 67-72.

Edinburgh Group. (2012).Growing the global economy through SMEs. Retrieved April 20, 2018, from http://www.edinburgh-group.org: http://www.edinburghgroup.org/media/2776/edinburgh_group_research_growing_the_global _economy_through_smes.pdf

Gladwell, M., (2010).Outliers: The Story of Success.Malcome Gladwell and Little, Brown and Company 
Hisrich, R. D., Peters, M. P., and Shepherd, D. A. (2010).Entrepreneurship (8th ed.).New York, United States of America: McGraw-Hill/Irwin.

Hewapathirana, G. I., (2009).Internationalization of Small Business:Multiple Case Studies of Successful Small Business Managers in Sri Lanka.

Hofstede, G., Noorderhaven, N., Thurik, R., Uhlaner, L. M., and Wennekers, A. R. (2004).Culture's Role in Entrepreneurship: Self-Employment Out of Dissatisfaction.Innovation, Entrepreneurship and Culture: The Interaction between Technology, Progress and Economic

Karra, N., Phillips, N., and Tracey, P. (2008).Building the Born Global Firms: Developing Entrepreneurial Capabilities for International New venture Success.Long Range Planning, pp.440-458.

King, D. M., (2015).Preschool Montessori Education in Sri Lanka: An overview. http://www.island.lk/index.php?page_cat=article-details\&page=articledetails\&code_title $=137161$

Lages, L. F., and Montgomery, D. B. (2004).Export performance as an antecedent of export commitment and marketing strategy adaptation: Evidence from small and medium-sized exporters.European Journal of Marketing , 38 (9/10).

Liyanage, I.M.K., (2014).Education System of Sri Lanka: Strengths and Weaknesses.http://www.ide.go.jp/library/Japanese/Publish/Download/R eport/2013/pdf/C02_ch7.pdf

McDougall, P. P., Scott, S., and Oviatt, B. M. (1994).Explaining the formation of international new ventures: The limits of theories from international business research. Journal of Business Venturing, Vol. 9 No 6,pp. 469-487.

Mudalige, D. M., Ismail, N. A., \& Malek, M. (2019).Exploring the Role of Individual Level and Firm Level Dynamic Capabilities in SMEs' internationalization.Journal of International Entrepreneurship, Vol.17 No 01

Oviatt, B. M., and McDougall, P. P. (2005).Defining International Entrepreneurship and Modeling the Speed of Internationalization.Entrepreneurship Theory and Practice

Obrecht, J.-J. (2004).Entrepreneurial capabilities: a resource- based systemic approach to international entrepreneurship.Handbook of Research on International Entrepreneurship . 
Praag, C. M., and Versloot, P. H. (2007).What is the value of entrepreneurship? A review of recent research.Vol.29 No 4, pp.351-382.

Pennings, J. M., Lee, K., and Witteloostuijn, A. v. (1998).Human Capital, Social Capital and Firm Dissolution. The Academy of Management Journal,Vol. 41 No 4, pp.425-440.

Patton, M. Q. (2002).Qualitative Research and Evaluation Methods (3rd Edition ed.), Sage Publication.

Ranasinghe, S. B. (2008).Factors Contributing to the Success of Women Entrepreneurs in Sri Lanka.

Roberts, E. B. (1991).Entrepreneurs in High Technology, Oxford University Press.

Nijsen, A. (2002).New relationships between public and private spheres. Socially responsible undertakings.Rencontres de St Gall 2002, Swiss Research Institute of Small Business and Entrepreneurship

Root-Bernstein, R., (2009).Multiple Giftedness in Adults: The Case of Polymaths. International Handbook on Giftedness.

Sriyani, G. W. (2010).Human Capital and its impact on Small Firm Success.International Conference on Business and Information .

Sirisena, P. (2015).Problems with Youth Entrepreneurship in Sri Lanka.Entrepreneurship and Business.

Stake, R. E. (1994.Case Studies: In N.K. Denzin, and Y.S. Lincoln. Eds, Hand book of Qualitative research .

Smith, R., and Anderson, A. R. (2004).The devil is in the e-tale: forms and structures in entrepreneurial narratives. Narrative and Discursive Approaches in Entrepreneurship.

Treasure, K., (2010). Importance of International Entrepreneurship. https://www.sagepub.com/sites/default/files/upmbinaries/47542_ch_1.pdf

Wach, K., and Wehrmann, C. (2014).Entrepreneurship in International Business: International Entre- preneurship as the Intersection of Two Fields.International Entrepreneurship and Corporate Growth in Visegrad Countries, Vol.9 No 22 
Wager, T. H. (1998).Determinants of human resource management practices in small firms: some evidence from Atlantic Canada.Journal of Small Business Management.

Yin, R. K. (2003).Case Study Research: Design and Methods (3rd edition ed.). Thousand Oaks, CA :Sage

Zhang, M., Tansuhaj, P., and McCullough, J. (2009).International entrepreneurial capability: The measurement and a comparison between born global firms and traditional exporters in China.Journal of International Entrepreneurship, Vol.7 No 4

Zahra, S. A., Neubaum , D. O., and Huse, M. (2008).Entrepreneurship in mediumsize companies: exploring the effects of ownership and governance systems.Journal of Management .

Zhang, M., Tansuhaj, P., and McCullough, J., (2009).International entrepreneurial capability: The measurement and a comparison between born global firms and traditional exporters in China.Journal of International Entrepreneurship, Vol. 7, issue 4, 292-322 